Galaxea, JCRS, 7: $23-36$ (2005)

\title{
沖縄本島真栄田岬一帯の琉球層群の層序
}

\section{Stratigraphy of the Ryukyu Group in Maeda-misaki area, Okinawa-jima, Ryukyu Islands, Japan}

\author{
Atsuko Muraoka ${ }^{1}$, Yasufumi $\operatorname{Iryu}^{1 *}$, Kei Odawara ${ }^{1,2}$, Tsutomu Yamada ${ }^{1}$, \\ Tokiyuki Sato $^{3}$
}

村岡暖子 $^{1} \cdot$ 井龍康文 $^{1 *}$ ・ 小田原 $\quad$ 䓵 $^{1,2}$ ・ 山田 努 $^{1}$ ・佐藤時幸 ${ }^{3}$

1 東北大学大学院理学研究科地学専攻地圏進化学講座

Institute of Geology and Paleontology, Graduate School of Science, Tohoku University. Aobayama, Sendai 980-8578, Japan

e-mail: iryu@dges.tohoku.ac.jp

神奈川県温泉地学研究所

Hot Springs Research Institute of Kanagawa Prefecture. Iriuda 586, Odawara, 250-0031 Japan

3 秋田大学工学資源学部地球資源学科応用地球科学教室

Institute of Applied Earth Sciences, Akita University. Tegatagakuen-machi 1-1, Akita 010-8502, Japan

\begin{abstract}
The Pleistocene Ryukyu Group consisting mainly of reef-complex deposits is exposed in Maeda-misaki area, central part of Okinawa-jima, Ryukyu Islands, southwestern Japan. The Pleistocene sequence, unconformably overlying pre-Tertiary phyllite of the Nago Formation, comprises the Quaternary Ryukyu Group and Holocene beach and alluvial deposits in this area. The Ryukyu Group consists of the Sobe Formation which is unconformably overlain by younger limestones. The Sobe Formation, the main body of the group, reaches $35 \mathrm{~m}$ in thickness and crops out at elevations of up to $90 \mathrm{~m}$. Five lithologic units have been identified in the carbonate sequence of the Sobe Formation in the neighboring area Yomitan and are numbered sequentially from the base upwards (Units 1-5). Of these, four units (Units 2-5) extend in the study area. Unit 2 is composed chiefly of conglomerate and sandy to gravelly limestone. Each of Units 3 and 4 consists of shallow-water coral limestone grading upward into deep-water deposits (rhodolith, Cycloclypeus-Operculina, and detrital limestones). Unit 5 is composed exclusively of coral limestone. The younger limestones are less than $4 \mathrm{~m}$ in thickness, rest unconformably on the Sobe Formation, and include detrital and coral limestones. These limestones are found at 3 sites at elevations of $<\sim 30 \mathrm{~m}$ on the coast of the study area. The stratigraphic relationship between the detrital and coral limestones remains unknown due to their limited occurrences. Nannofossil biostratigraphy indicates the sandy limestone of Unit 2 of the Sobe Formation ranges in age from 0.41 to $1.65 \mathrm{Ma}$.
\end{abstract}

Key words: Ryukyu Islands, Okinawa-jima, Sobe Formation, Pleistocene, carbonate, stratigraphy

*Corresponding author: iryu@dges.tohoku.ac.jp

TEL: 022-795-6622, FAX: 022-795-6634

はじめに

琉球列島は、太平洋のサンゴ礁域の中で高緯度に 位置するにも関わらず、島々の周囲にはサンゴ礁が よく発達し、また陸上には、サンゴ礁から陸棚まで
の堆積物よりなる更新統琉球層群が広く分布する。 琉球層群は、第四紀の気候変動・海水準変動に規制 されて堆積したことが明らかとなっており (Nakamori 1986; Nakamori et al. 1995; Iryu et al. 1998; Sagawa et al. 2001)、同層群を琉球列 
島全域にわたつて網羅的に検討することが、第四紀 の気候変動・海水準変動および北西太平洋高緯度礁 の形成発達史の解明に繋がると期待されている（井 龍・松田1999；松田ほか 2003)。このような背景 のもと、小田原ほか（2005）は、本研究の調査地 域に隣接する読谷村一帯の琉球層群の層序について 検討を行い、同村一帯の琉球層群は、伊良皆層とそ れを不整合に覆う楚辺層からなることを明らかにし た。伊良皆層は地表には露出せず、碟岩と著しい再 結晶作用を被つた石灰岩（サンゴ石灰岩と砕屑性石 灰岩）よりなるとされた。また楚辺層は、5つのユ ニットから構成され、ユニット $1 、 2$ から検出され た石灰質ナンノ化石は $0.41 \sim 0.85 \mathrm{Ma}$ という年代值 を示すと報告された。しかし彼らの研究は、Flint et al. (1959) 以来、沖縄本島の琉球層群の研究上、 重要なフィールドとみなされている読谷地域に調査 地域を限定したため、長浜川より北東側の、恩納村 真栄田岬一带に分布する琉球層群については検討さ れなかった。そこで本研究では小田原ほか（2005） の調査地域の北東側に隣接する恩納村真栄田岬一带 を調査域に設定し、琉球層群の層序を検討した。そ
の結果、本地域の琉球層群は、楚辺層のユニット 2 〜 5 と、その上位に不整合で重なる新期石灰岩から なることが判明した（Figs. 1〜 3)。ここにその成 果を報告する。

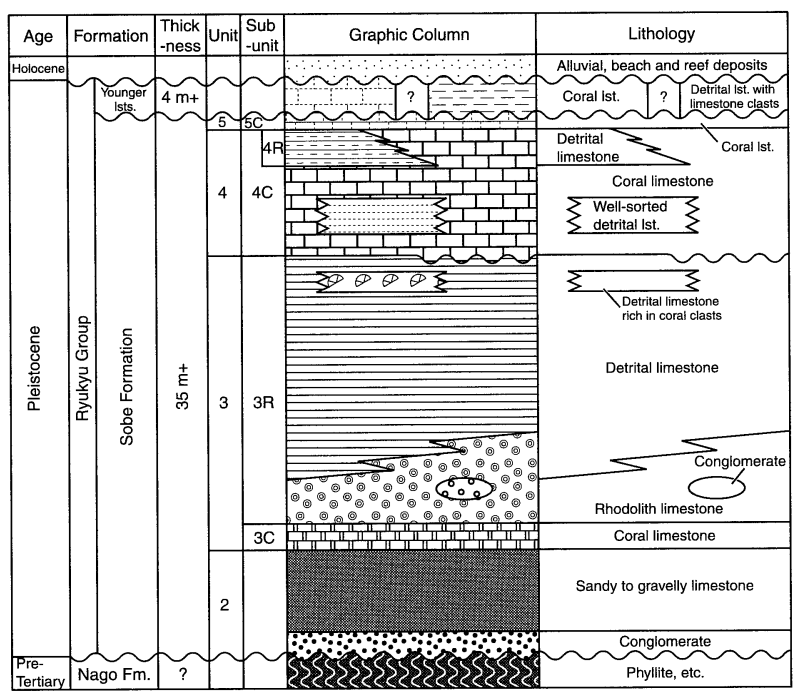

Fig. 1. Schematic representation of the lithostratigraphy of the Ryukyu Group in Maeda-misaki area.

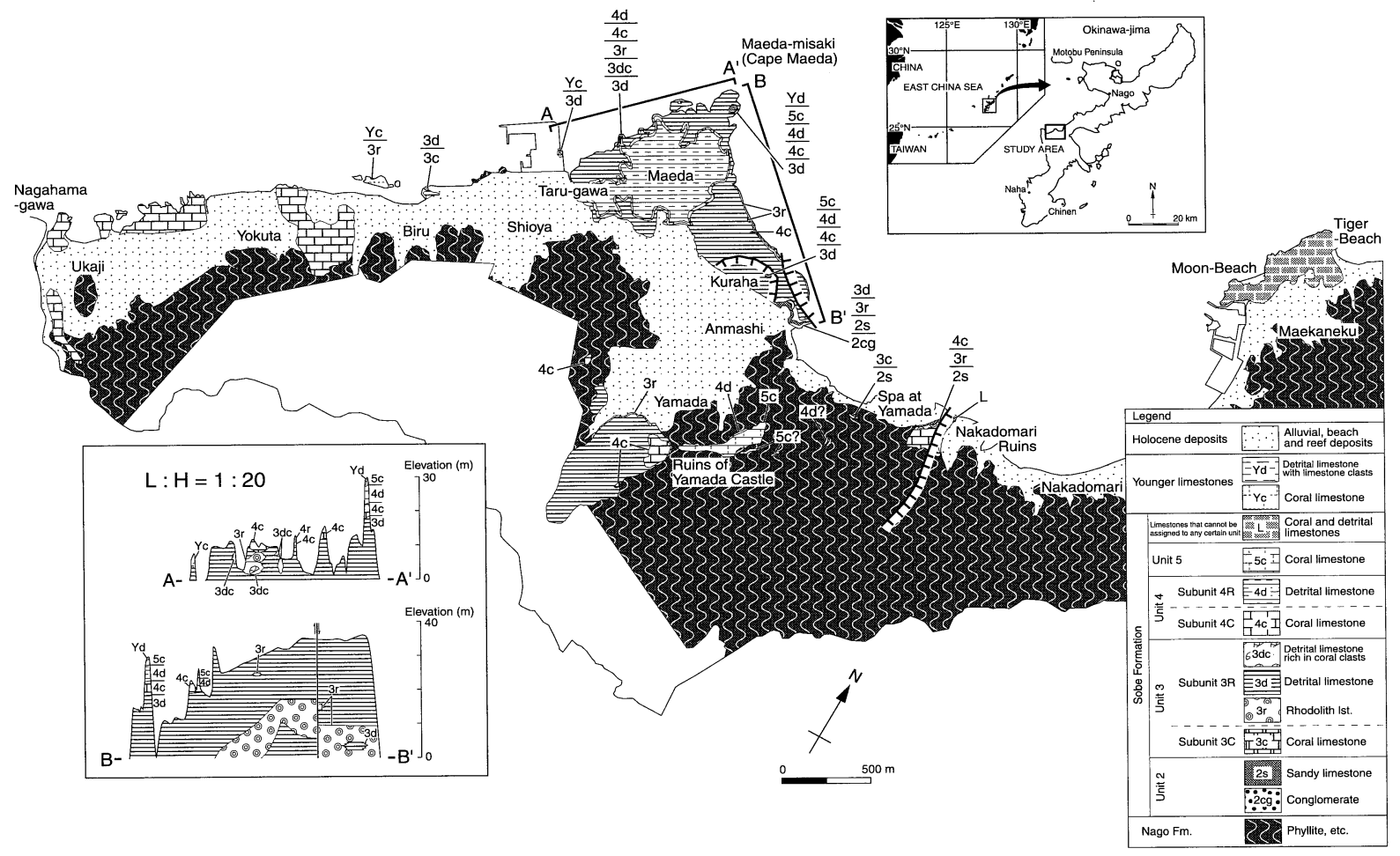

Fig. 2. Geologic map of the Ryukyu Group in the study area. Inset shows geologic cross-sections along the coastlines A-A' and B-B'. 

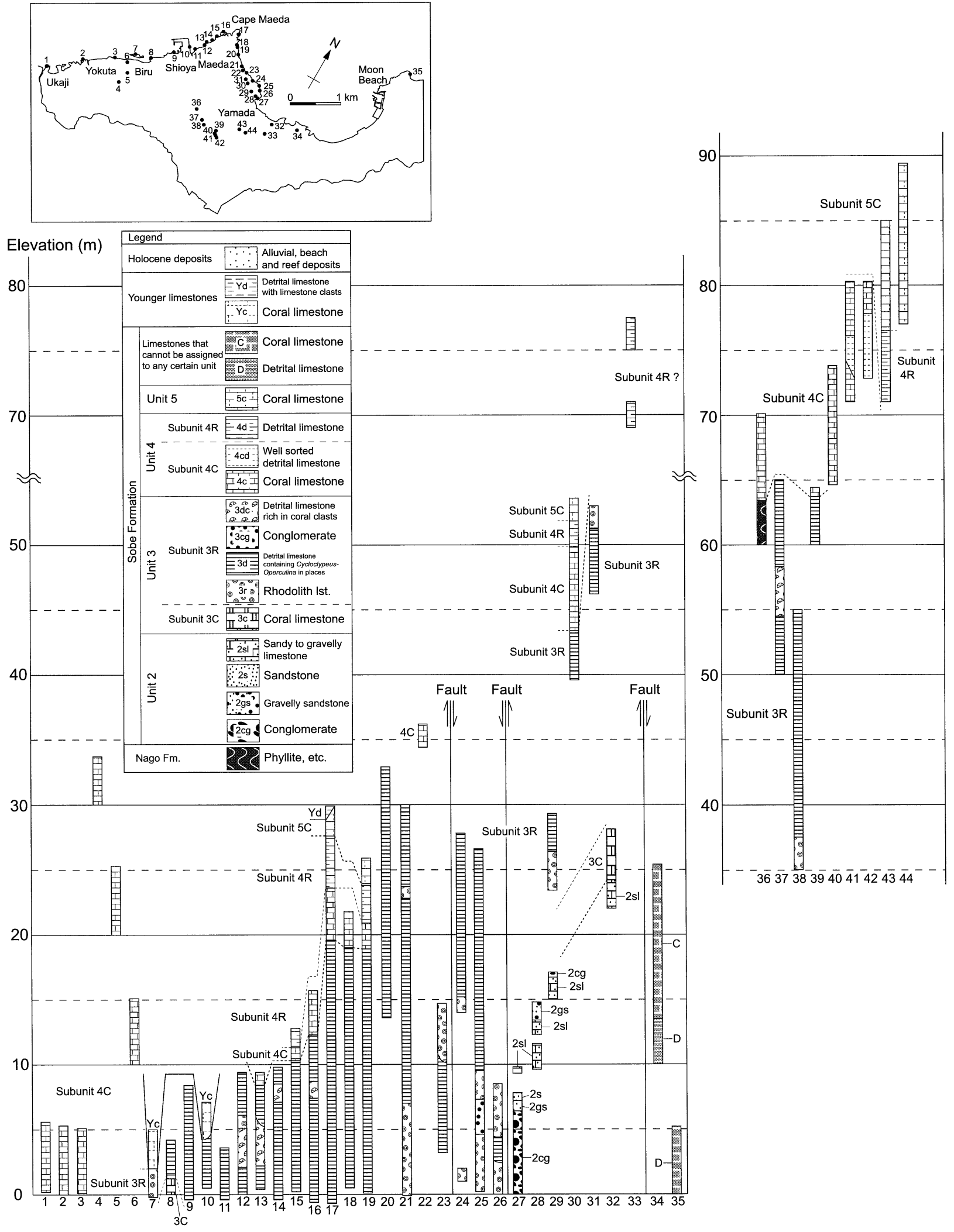

Fig. 3. Selected columnar sections of the Ryukyu Group in the study area. 


\section{研究方法}

本研究では、1/10,000の地形図を用いて地表踏査 を行い、地質図と柱状図（1/100）を作成した。岩 相区分は、露頭観察および岩石薄片の顕微鏡観察に 基づいて行った。本論文では、琉球層群の岩相区分 は井龍ほか (1992)、Iryu et al. (1998)、Nakamori et al. (1995) を踏襲する。また、ユニットおよび サブユニットの定義は小田原・井龍（1999）に従 う。なお、ユニット 2 は主に砅岩および砂質〜碩質 石灰岩よりなり、浅海相と沖合相を厳密に区別でき なかったため、サブユニットに細分しなかった。石 灰質ナンノ化石の検討手法は、佐藤ほか（2004） に従った。

\section{研究史}

琉球層群の研究は 100 年を超える歴史を有し、こ れまで様々な研究が行われてきた。なお、琉球層群 全体の研究史は井龍ほか（1992）によって、隣接 する読谷地域の琉球層群の研究史は小田原ほか （2005）によって詳しく論じられているので、本論 では省略する。

本研究の調査地域である恩納村真栄田岬一帯の琉 球層群について言及した論文は、Takayasu （1978）のみである。彼は、山田温泉（現ルネッサ ンスリゾートオキナワ）向かいの露頭には、下位よ り非石灰質砂岩、琉球層群（=本体型石灰岩）下部 層および上部層（A、B部層）がみられ、また、芕 幸山ハブセンター (現琉球村) 向かいの露頭では、 琉球層群下部層および上部層（ $\mathrm{A} \sim \mathrm{C}$ 部層）がみら れると述べた。

\section{調査地域の位置および地形}

本研究の調査地域である沖縄県恩納村は那龩市の 北北東約 $30 \mathrm{~km}$ に位置し、東経 $127^{\circ} 45^{\circ} \sim 56^{\prime}$ 、北緯 $26^{\circ} 25^{\prime} \sim 32^{\prime}$ の範囲にあり、総面積は50.77 $\mathrm{km}^{2}$ である。 調査地域は、南限・西限を読谷村との村境、北限 東限をタイガービーチとする、南北 $4.2 \mathrm{~km}$ 、東西 6.4 kmの範囲にある (Fig. 2)。

本調査地域では、基盤岩（多護層）から構成され
る山塊が海岸付近までせまり、琉球層群の分布は海 岸部および内陸部の山田城趾付近に限られる。基盤 岩の分布域では地形の起伏か激しく、樹枝状の水系 が発達するのに対し、琉球層群の分布域では地形の 起伏が息しく、明瞭な地表水系は認められない。本 調査地域内における琉球層群の分布の最高所は山田 城趾護佐丸琴父祖墓の西に位置する露頭（Fig. 3の44）

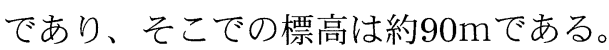

本調査地域と読谷村との境界には、北西方向に向 かって長浜川が流れる。長浜川から垂川にかけての 海岸部は主に比高が $5 \sim 10 \mathrm{~m}$ の断続的な崖となつ ているが、㝍久苗ビーチでは小規模な海浜がみられ る。垂川から真栄田岬にかけて、海岸の崖は徐々に 比高を増し、真栄田岬では $29.9 \mathrm{~m} に$ 達する。また、 真栄田岬から久良波にかけての海岸は比高が $30 \mathrm{~m}$ を越える断崖となっている。管埧志から仲泊南西に かけては山塊が海岸までせまっているが、仲泊や前 架久には標高 $10 \mathrm{~m}$ 以下の平地がみられる。前兼久 の北㧍よび西の海岸は、主に比高が 6 m前後の崖と なっており、ムーンビーチおよびタイガービーチで は小規模な海浜がみられる。真栄田岬から久良波に かけての急崖部を除けば、調查地域一带の海岸部に はサンゴ礁がよく発達し、礁原の幅は最大で約 1,500mに達する。

\section{地質概説}

調查地域の地質は、下位より先第三系名護層、更 新統琉球層群楚辺層および新期石灰岩、完新統の海 岸・低地堆積物よりなる (Figs. 1, 2, 3)。

名護層は、宇加地一垂川の内陸部および山田、仲 泊、前兼久一帯に露出し、主に泥質千枚岩より構成 される。楚辺層は、本地域の琉球層群の主体をなし、 調查地域の海岸部一帯および内陸部の山田城趾一帯 に分布する。本層は、サンゴ石灰岩、石灰藻球石灰 岩、Cycloclypeus-Operculina石灰岩、砕屑性石灰岩、 砂質〜磞質石灰岩、砂岩、䟧質砂岩、碩岩より構成 される。長浜川一与久田一帯、山田城趾一帯、およ び真栄田にはサンゴ石灰岩が広く分布する。同サン ゴ石灰岩は隣接する読谷地域の楚辺層サブユニット $4 \mathrm{C}$ のンゴ石灰岩（小田原ほか 2005）と対応づ けられ、下位層とは標高 $20 \mathrm{~m}$ 以上の地域で不整合、 $20 \mathrm{~m}$ 以下の地域で整合関係にある。これは、Flint 
et al. （1959）によって提唱された読谷石灰岩 (Yontan limestone) と対応づけられる。真栄田岬 頂部（Fig. 3の17）、美留の海岸の北西約50mに位 置する小島（Fig. 3の 7 ）、塩屋漁港内漁業センター 脇の露頭（Fig. 3の10）では、楚辺層を不整合関係 で覆うサンゴ石灰岩や、楚辺層に由来する石灰岩の 䃯を含有する砕屑性石灰岩がみられる。これらの石 灰岩は、楚辺層上に不整合関係で重なるという共通 した層位学的位置にあるものの、分布が孤立してお り、それら相互の関係は不明であるため、特定の層 名を付さず、新期石灰岩として一括する。また、海 岸および低地堆積物は、サンゴ礁、海浜砂、砂丘砂、 ビーチロック、風化残留土などさまざまな堆積物か らなるが、本論文ではこれらを一括して特定の層名 は付さないことにする。

\section{琉球層群の層序}

\section{1. 楚辺層（Sobe Formation）}

〈命名〉小田原ほか（2005）。

〈模式地〉沖縄県読谷村楚辺の採石場（=森岡コー リー)。なお、副模式地として同村長浜の牧港 ヒューム管工業所敷地内の崖が指定されている （小田原ほか2005）。

〈層厚〉本調査地域では $35 \mathrm{~m}$ 以上。

〈分布〉読谷村から恩納村の国道58号線より西側 一帯。調查地域では、海岸部一帯および内陸部 の山田城趾一帯に分布する。

〈定義〉読谷村および恩納村に分布する琉球層群の 主部。名護層、座喜味層、琉球層群伊良皆層を 不整合に覆う。

\section{1. 長浜川から真栄田岬にかけての層序}

小田原ほか（2005）は、楚辺層を5つのユニッ トに区分した。彼らは、楚辺層の副模式地である牧 港ヒューム管工業所敷地内の崖には、サブユニット 2 Rから 5 Cまでが露出するとし、長浜一帯には、 サブユニット $4 \mathrm{C}$ のンゴ石灰岩が広く分布すると した。このサブユニット $4 \mathrm{C}$ のンゴ石灰岩は、長 浜川を挟んで、本研究の調査地域内の宇加地、与久 田一帯に広く分布し（Fig. 3の $1 \sim 6$ )、長浜川の 北東方約 $1700 \mathrm{~m}$ の地点まで追跡される。これより 北東では約 $1600 \mathrm{~m}$ にたり露出を欠くが、真栄田
岬の南西約700mの地点（Fig. 3の13）で再び露出 する。本サンゴ石灰岩は半球状〜卓状サンゴに富む。

美留の海岸の北西約 $50 \mathrm{~m}$ に位置する小島（Fig. 3 の 7 ）では、露頭下部に石灰藻球石灰岩（層厚 2.2 m）がみられ、これは新期石灰岩に含められるサン ゴ石灰岩（層厚 $3.0 \mathrm{~m}$ ）に明瞭な境界をもって不整 合で覆われる（Fig. 4A）。石灰藻球石灰岩は、球 径が $4 \mathrm{~cm}$ 以下の不規則な形状の石灰藻球を多く含み、 Operculina、Cycloclypeus や非石灰質粒子を伴う。長 浜川〜与久田の一帯では、サブユニット $4 \mathrm{C}$ のサ ゴ石灰岩が広く分布しており、石灰藻球石灰岩は、 本露頭で認められるの夕である。両者の直接の関係 は不明であるが、サブユニット $4 \mathrm{C}$ のンゴ石灰岩 がより地形的に高所まで分布しているので、この石 灰藻球石灰岩はサブユニット $4 \mathrm{C}$ のンゴ石灰岩よ り下位、おそらくサブユニット $3 \mathrm{R}$ に含められると 判断される。

美留の親鸞聖人像裏の露頭（Fig. 3 の 8 ）では、 海浜付近にサブユニット $3 \mathrm{C}$ のンゴ石灰岩（層厚 $1.5 \mathrm{~m} ）$ が確認され、これはサブユニット $3 \mathrm{R}$ の砕 屑性石灰岩（層厚 $2.7 \mathrm{~m}$ ）に覆われる。サンゴ石灰 岩には、卓状〜薄板状のキクメイシ科のサンゴが少 量含まれ、下部 $70 \mathrm{~cm} に は$ 名護層に由来する千枚岩 の偏平な細礫が認められる。砕屑性石灰岩はサンゴ 石灰岩の上位に整合漸移の関係で重なり、異地性サ ンゴが少量含まれる。また、上部1.8mはやや砂質 であり、最上部 $0.8 \mathrm{~m}$ は弱く成層している。サブユ ニット $3 \mathrm{R}$ の砕屑性石灰岩は、ここより北東に真栄 田岬まで追跡され、真栄田一帯に広く分布する。塩 屋漁港内漁業センター脇の露頭（Fig. 3の10）では、 サブユニット $3 \mathrm{R}$ の砕屑性石灰岩（層厚3.8 4.2m） の上位に明瞭な境界をもつて新期石灰岩に含められ るサンゴ石灰岩（層厚2.4 2.8m）が重なる（Fig. $4 \mathrm{~B})$ 。砕屑性石灰岩の最下部より 2.0 2.8mの範囲 には無節サンゴモが、同2.8〜 4.2mには造礁サンゴ が多くみられ、最上部は起伏に富み、著しく赤色化 している。本地点を起点として北東に約 $200 \mathrm{~m} の 区$ 域（海岸部）に分布するサブユニット $3 \mathrm{R}$ の砕屑性 石灰岩の露頭上面は赤色を呈している。真栄田岬の 南西約700mの地点（Fig. 3の13）では、サブユニッ ト $3 \mathrm{R}$ の砕屑性石灰岩（層厚 $8.0 \mathrm{~m}$ ）の上位にサブ ユニット $4 \mathrm{C}$ ユンゴ石灰岩（層厚 $1.0 \mathrm{~m}$ ） が整合 漸移の関係で重なる。砕屑性石灰岩は最下部より 1.8～5.5mに造礁サンゴに富む層（層厚3.0〜 $3.7 \mathrm{~m}$ ） 

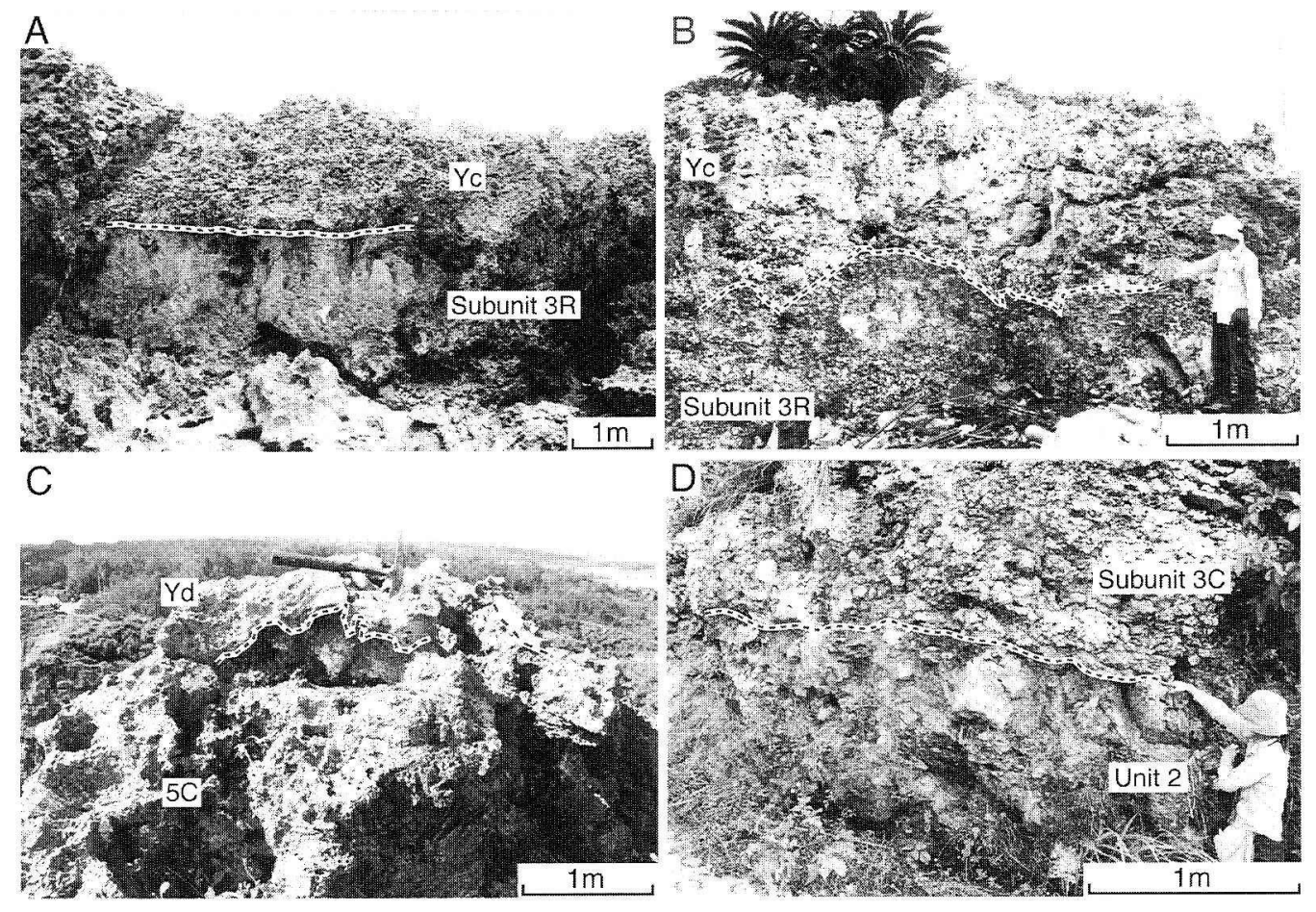

Fig. 4. Outcrop photographs of the Ryukyu Group in the study area. Broken lines indicate unit boundaries.

A. Coral limestone (Yc) of the younger limestones unconformably overlying rhodolith limestone (Subunit 3R) of the Sobe Formation that crops out near Biru (Fig. 3-7).

B. Coral limestone $\left(\mathrm{Yc}_{\mathrm{c}}\right.$ ) of the younger limestones resting unconformably on detrital limestone rich in coral clasts (Subunit 3R) of the Sobe Formation at an outcrop near Shioya Fishery Port (Fig. 3-10).

C. Coral limestone (Subunit 5C) of the Sobe Formation unconformably overlain by detrital limestone (Yd) of the younger limestones at Maeda-misaki (Cape Maeda) (Fig. 3-17).

D. Unit 2 and Subunit 3C of the Sobe Formation at an outcrop to the south of Yamada Spa (Fig. 3-32). Note gravelly limestone of Unit 2 is overlain by coral limestone of Subunit 3C. The lower interval $(80 \mathrm{~cm}$ thick) of the coral limestone contains up to pebble-sized lithoclasts derived from the Nago Formation.

を、同 4.8〜 8.0mに石灰藻球を比較的多く含む層 （層厚2.5～3.2m）を挟有する。サンゴ石灰岩には、 半球状〜卓状サンゴが比較的多く含まれる。サブユ ニット $4 \mathrm{C}$ サンゴ石灰岩は北東へ真栄田岬まで追 跡されるが、岬に向かい徐々にその分布高度を上げ、 真栄田岬の南西約 $700 \mathrm{~m}$ の地点（Fig. 3の13）にお いて標高 $8.4 \mathrm{~m}$ にあった下限は、真栄田岬では標高 $19.6 \mathrm{~m}$ に達する。真栄田岬の南西約 $450 \mathrm{~m}$ の地点 (Fig. 3の15）では、下位よりサブユニット $3 \mathrm{R} の$ 砕屑性石灰岩（層厚 $10.1 \mathrm{~m}$ )、サブユニット $4 \mathrm{C}$ 、 サンゴ石灰岩（層厚 $1.0 \mathrm{~m}$ )、サブユニット $4 \mathrm{R}$ 砕 屑性石灰岩（層厚 $1.5 \mathrm{~m}$ ） が重なる。サブユニット $3 \mathrm{R}$ 砕屑性石灰岩には、最下部より0〜6 mには 名護層に由来する細粒砂大の砕屑粒子が、同 $9 \mathrm{~m} に$ は葉状の無節サンゴモが含まれる。また、同2.5〜 2.9m、5.2〜 7.5mにはOperculinaが比較的多く含ま
れる。同砕㾍性石灰岩は上位のサブユニット $4 \mathrm{C} の$ サンゴ石灰岩に整合漸移の関係で覆われる。このサ ンゴ石灰岩は、上位の緻密で白色を呈するサブユニッ 卜4 Rの砕屑性石灰岩に漸移する。本砕屑性石灭岩 は無節サンゴモに富み、Operculinaや石灰藻球の破 片を含む。塩屋漁港から真栄田岬にかけての範囲で は、サブユニット $3 \mathrm{R}$ 砤屑性石灰岩中に造礁サン ゴに富む層が挟在する。これらの造礁サンゴの多く は、生息時の姿勢を保っておらず、骨格が摩耗して おり、異地性のものと判断される。しかし、一部は 成長方向が地層の上位方向と一致し、比較的骨格が よく保存されており、現地性の可能性も否定できな い。この造礁サンゴに富む層は極めて連続性に乏し く、また分布高度・層厚の側方変化が激しい。 


\section{2. 真栄田岬における層序}

真栄田岬（Fig. 3の17）には琉球層群楚辺層が露 出し、その層厚は $30 \mathrm{~m}$ 以上に達する。本地点にお ける最下位層は、サブユニット $3 \mathrm{R}$ の砕屑性石灰岩 （層厚 $20.3 \mathrm{~m}$ ）である。本砕屑性石灰岩は最下部よ り 0 ～7.1mは塊状無層理であるが、同7.1〜20.3m は弱く成層している。最下部より5.1〜 5.8mにはサ ンゴの砂が少量含まれており、同 $7.1 \mathrm{~m}$ 付近には Operculinaが比較的多く認められる。本砕屑性石灰 岩は上位のサブユニット $4 \mathrm{C}$ のンゴ石灰岩（層厚 $4.0 \mathrm{~m} ）$ と比較的明瞭な境界で接する。本サンゴ石 灰岩の最下部は部分的に赤色を帯び、卓状サンゴを 多く含む。下部 $2 \mathrm{~m}$ に含まれるサンゴは、無節サン ゴモにより覆われている。また、上部 $2 \mathrm{~m}$ は、細礫 大以下の凝灰岩片および石英粒子を含む。本サンゴ 石灰岩の上位にはサブユニット $4 \mathrm{R}$ 砕屑性石灰岩 （層厚 $4.0 \mathrm{~m}$ ）が重なり、両者の境界に沿つてクラッ クが発達する。本砕屑性石灰岩は塊状無層理で、下 部10cmにはOperculinaがやや密集して産する。本砕 屑性石灰岩の最下部より $1.3 \mathrm{~m}$ 付近では、葉片状の サンゴモが比較的多くみられ、同 $2.6 \mathrm{~m} に は$ 異地性 サンゴが認められる。また、本砕屑性石灰岩の上部 $40 \mathrm{~cm}$ は石灰藻球をわずかに含む。この石灰藻球は 不規則な形状を呈し、主に無節サンゴモよりなる薄 い被覆部（<2 mm） を有する。本砕屑性石灰岩は上 位のサブユニット $5 \mathrm{C}$ のンゴ石灰岩（層厚1.2〜 $2.3 \mathrm{~m} ）$ に漸移する。本サンゴ石灰岩は卓状〜薄板 状サンゴを比較的多く含み、上部 $70 \mathrm{~cm}$ では無節サ ンゴモが伴ってみられる。本サンゴ石灰岩は、新期 石灰岩に含められる砕屑性石灰岩（層厚 $1.1 \mathrm{~m}$ ）に 不整合関係で覆われる (Fig. 4C)。

\section{3. 真栄田岬から久良波にかけての急崖における 層序}

真栄田〜久良波の急崖では、真栄田岬でみられた サブユニット $3 \mathrm{R} \sim 5 \mathrm{C}$ に含められる石灰岩が、岬 の南東約 $270 \mathrm{~m}$ の地点（Fig. 3の19）まで追跡され る。同地点より南東では、約 $770 \mathrm{~m}$ に渡つて、サブ ユニット $3 \mathrm{R}$ の砕屑性石灰岩と石灰藻球石灰岩がほ ぼ連続して分布する（Fig. 3の20～23）。真栄田岬 の南東約 $730 \mathrm{~m}$ の地点 (Fig. 3の21）では、石灰藻 球石灰岩（層厚 $7.0 \mathrm{~m}$ ）および砕屑性石灰岩（層厚 $23.3 \mathrm{~m})$ が露出する。石灰藻球石灰岩の最下部より 3.8〜 4.9mは中粒砂〜中碟大の非石灰質砕屑物に富
む。砕屑性石灰岩は、塊状無層理で非石灰質砕屑物 を少量含み、最下部より13.1～15.9mは名護層に由 来する中礫大以下の亜円礫に富む。また、同15.9〜 $16.8 \mathrm{~m}$ に石灰藻球石灰岩層（層厚 $0.9 \mathrm{~m}$ ）を挟有す る。真栄田岬の南東約 $870 \mathrm{~m}$ の地点 (Fig. 3の23) では、名護層に由来する砕屑物に富む砕屑性石灰岩 (層厚6.9 7.5m）の上位に、石灰藻球石灰岩（層 厚4.0〜 4.6m）が比較的明瞭な境界をもつて重なる。 砕屑性石灰岩は灰色を呈し、非石灰質砕屑物を含み、 弱く成層している。最下部より $0 \sim 3.7 \mathrm{~m}$ は石英や 千枚岩の細〜中礯大の亜円碟に富み、これらの碟は

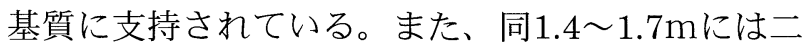
枚貝が密集しており、同3.7〜 7.2mは異地性の造礁 サンゴを含む。石灰藻球石灰岩は、最大球径 $8 \mathrm{~cm}$ ま での石灰藻球に富み、下位の砕屑性石灰岩を削り込 んで堆積している。真栄田岬の南東約 $1000 \mathrm{~m}$ から 1 400mにかけての範囲は、北西〜南東方向に延びる 正断層により北東側が約 $8 \sim 12 \mathrm{~m}$ 落ちている。断 層の北東側には、サブユニット $3 \mathrm{R}$ の砕屑性石灰岩 と石灰藻球石灰岩がほぼ連続して露出する。真栄田 岬の南東約 $1050 \mathrm{~m}$ の地点（Fig. 3の24）では、露 頭最下部に石灰藻球石灰岩（層厚 $1 \mathrm{~m}$ ）があり、露 頭の欠如部（層厚 $12 \mathrm{~m}$ に相当）を挟んで、その上 位には、石灰藻球石灰岩（層厚 $1.2 \mathrm{~m}$ ）および砕屑 性石灰岩（層厚12.6m）が露出する。砕屑性石灰岩 は、塊状無層理で、最下部より 5.2〜 5.4mには基盤 の名護層に由来する礫が少量認められる。真栄田岬 の南東約 $1150 \mathrm{~m}$ の地点（Fig. 3の25）では、石灰 藻球石灰岩（層厚 $9.3 \mathrm{~m}$ ） および砕屑性石灰岩（層 厚 $17.1 \mathrm{~m} ）$ がみられる。石灰藻球石灰岩の最下部よ り 0 ～ 2 mには、細碟大の緑色岩および石英の亜円 碟が含まれる。また、最下部より 4.4〜 7.1mには、 中碟大までの石英や緑色岩の円礫に富む碟岩が挟在 する。本碩岩は、下位の石灰藻球石灰岩とは明瞭な 境界をもって接し、上位の石灰藻球石灰岩とは漸移 関係にある。本碟岩は碟支持の組織をなし、基質は 名護層起源の砕屑粒子に富む砕屑性石灰岩である。 礫岩の上半部には、石灰藻球が散在する。石灰藻球 石灰岩の上位に重なる砕屑性石灰岩は、灰色を呈し、 塊状無層理で、非石灰質砕屑物を少量含む。最上部 $40 \mathrm{~cm}$ は弱く成層している。

一方、断層の南西側から久良波の東では、陸源性 砕屑物に富む堆積物がみられる（Fig. 3の 27、28、 29）。本堆積物は、サブユニット $3 \mathrm{R}$ の石灰藻球石 
灰岩より下位に位置することは確実である（Fig. 3 の29)。また、断層の南西側の海岸（Fig. 3の27付 近）では、細礫大までの陸源性砕屑物を含み，淡褐 色を呈する砂質石灰岩と、薄板状の造礁サンゴを含 むサンゴ石灰岩が接する岩塊がまれに見出される。 造礁サンゴの成長方向から、サンゴ石灰岩が上位と 推定される。よって、この付近では、陸源性砕屑物 に富む堆積物、サンゴ石灰岩、石灰藻球石灰岩等の サブユニット $3 \mathrm{R}$ の石灰岩という累重関係が想定さ れ、陸源性砕屑物に富む堆積物はユニット 2 に、サ ンゴ石灰岩はサブユニット $3 \mathrm{C}$ 含めるのが最も妥 当と思われる。断層の南西側の露頭（Fig. 3の27） では、ユニット 2 の碟岩（層厚 $6.4 \mathrm{~m}$ )、碟質砂岩 （層厚 $0.8 \mathrm{~m}$ )、中粒砂岩（層厚 $0.6 \mathrm{~m}$ )、礫質石灰岩 （層厚 $0.5 \mathrm{~m}$ ） が観察される。碟岩は主に細〜中礫大 の石英や千枚岩の亜円礫より構成され、それらの礫 は礫支持の組織をなす。最下部より $0.9 \sim 1.5 \mathrm{~m}$ は赤 色を呈し、同2.6 3.8mは弱く成層している。また、 同3.8〜 4.4m は部分的に固結しており、同 $4.4 \sim 4.5$ $\mathrm{m}$ には赤色粘土層を挟有する。粘土層の下位は石英 の礫が多く、上位では石英の他に、千枚岩の礫が多 くみられる。また、粘土層の直上 $45 \mathrm{~cm}$ （最下部よ り 4.5〜4.95m）は、礫のサイズが大きく、中〜大 碟大の石英、千枚岩の礫が含まれる。本碟岩は海棲 生物化石を欠くことから、陸成層である可能性があ る。碟質砂岩は、浮遊性有孔虫などの生砕物を含み、 これは上位の塊状無層理の中粒砂岩に漸移する。こ の上位には、露頭の欠如部（層厚 $1.5 \mathrm{~m}$ に相当）を 挟んで、層理の発達した礫質石灰岩（層厚 $0.5 \mathrm{~m}$ ） が露出する。真栄田岬〜久良波の急崖における久良 波側基部の露頭（Fig. 3の28）では、ユニット2の 砂質石灰岩がみられる。砂質石灰岩（層厚 $2.0 \mathrm{~m}$ ) の最下部より 10～25cmは基盤の名護層に由来する 中礫大以下の円礫に富み、同25〜 75cmはOperculina を比較的多く含む。この上位には、露頭欠如部（層 厚 $0.7 \mathrm{~m}$ に相当）を挟み、砂質〜碟質石灰岩（層厚 $1.1 \mathrm{~m})$ および礫質砂岩 $(1.4 \mathrm{~m})$ が露出する。砂質 〜礫質石灰岩は、最下部 $20 \mathrm{~cm}$ 除き、ラミナが発 達しており、同0.9〜 $1.1 \mathrm{~m} に は$ 斜交層理が発達する。 碩質砂岩はよく成層しており、砕屑性石灰岩の薄層 を挟有する。また、本砶質砂岩にはOperculinaが多 く含まれ、上部には生痕化石（サンドパイプ）が認 められる。久良波の東約 $130 \mathrm{~m}$ 露頭 (Fig. 3の29) では、露頭最下部にユニット 2 の砂質石灰岩（層厚
$1.7 \mathrm{~m}$ ）および中礫岩（層厚 $0.4 \mathrm{~m} ）$ があり、露頭の 欠如部（層厚 $6.3 \mathrm{~m}$ に相当）を挟んで、その上位に はサブユニット $3 \mathrm{R}$ の石灰藻球石灰岩（層厚 $3.0 \mathrm{~m}$ ） および砕屑性石灰岩（層厚 $2.9 \mathrm{~m}$ ） が露出する。真 栄田岬ダイバーズハウスから久良波集落へ抜ける小 道沿いにある墓脇の露頭（Fig. 3の30）では、サブ ユニット $3 \mathrm{R} \sim 5 \mathrm{C}$ 累重関係が観察される。ここ では、下位よりサブユニット $3 \mathrm{R}$ の砕屑性石灰岩 (層厚 $3.8 \mathrm{~m}$ )、サブユニット $4 \mathrm{C}$ 、サンゴ石灰岩 (層厚 $6.5 \mathrm{~m}$ )、サブユニット $4 \mathrm{R}$ の砕屑性石灰岩 (層厚 $2.0 \mathrm{~m}$ )、サブユニット $5 \mathrm{C}$ （層厚 $1.7 \mathrm{~m}$ ）が、 この順で重なる。サブユニット $3 \mathrm{R}$ の砕屑性石灰岩 は無節サンゴモに富む。また、サブユニット $4 \mathrm{Cお}$ よびサブユニット $5 \mathrm{C}$ のンゴ石灰岩は、ともに卓 状サンゴに富み、無節サンゴモを少量伴う。真栄田 岬ダイバーズハウスの東約 $120 \mathrm{~m}$ の露頭（Fig. 3の 31）では、サブユニット $3 \mathrm{R}$ の砕屑性石灰岩（層厚 $5.0 \mathrm{~m} ）$ の上位に整合漸移の関係で石灰藻球石灰岩 （層厚 $1.8 \mathrm{~m}$ ）が重なる。砕屑性石灰岩は、名護層に 由来する中礫大以下の亜円磕に富み、Operculina、 サンゴ破片を伴う。石灰藻球石灰岩に含まれる石灰 藻球は球径が $1.6 \mathrm{~cm}$ 以下の不規則な形状を呈し、2 $\mathrm{mm}$ 以下の薄い被覆部を有する。この石灰藻球石灰岩 はCycloclypeusおよびサンゴ破片を伴う。

\section{4. 山田温泉からタイガービーチにかけての層序}

山田温泉からタイガービーチの海岸部には琉球層 群が分布する。仲泊遺跡より西側には、ユニット 2 とユニット 3 （サブユニット $3 \mathrm{C｝ \text {）の堆積物が分布 }}$ するほか、ユニット 4 （サブユニット $4 \mathrm{R}$ ）に含め られる可能性がある石灰岩がみられる。仲泊遺跡以 東に分布する琉球層群は、どのユニットに帰属する のかを特定できなかった。

沖縄養蜂振興入口の東約 $150 \mathrm{~m}$ の露頭（Fig. 3の 32）では、下位に碩質石灰岩（層厚 $2.3 \mathrm{~m}$ ）があり、 その上位に比較的明瞭な境界をもってサンゴ石灰岩 （層厚 $3.7 \mathrm{~m}$ ）が重なる（Fig. 4D）。礫質石灰岩は 塊状無層理で灰色を呈し、名護層に由来する石英や 千枚岩の細礫を多く含み、真栄田岬〜久良波の急崖 における久良波側基部に分布する砂質〜碟質石灰岩 （Fig. 3の28、29） と同様の岩相を示すことより、 ユニット 2 に含められる。本礫質石灰岩の最上部は やや赤色を呈する。砅質石灰岩の上位に位置するサ ンゴ石灰岩は、ユニット 3 （サブユニット $3 \mathrm{C｝ \text {）に }}$ 
含められる。サンゴ石灰岩の下部（層厚 $0.8 \mathrm{~m}$ ）は 中礫大の碟に富み、二枚貝、サンゴ破片を伴う。こ れらの岩片・生砕物は、無節サンゴモを主とする被 覆生物により覆われているが、被覆部の厚さは $2 \mathrm{~mm}$ を超えない。サンゴ石灰岩は卓状サンゴを多く含み、 無節サンゴモを伴う。また、サンゴ石灰岩の基底よ り $2.3 \mathrm{~m}$ 付近では枝状サンゴ (Euphyllia ? sp.) が みられる。沖縄養蜂振興入口の南約 $260 \mathrm{~m}$ の露頭 （Fig. 3の33）には、砕屑性石灰岩が露出する。本 露頭では、下位に、中礫大までの石英および千枚岩 の亜円碟に富み、灰色を呈する砕屑性石灰岩（層厚 $2 \mathrm{~m}$ ）があり、露頭の欠如部（層厚 $4 \mathrm{~m}$ に相当）を 挟んで、上位には細〜中粒砂大の非石灰質砕屑物、

Operculina、サンゴ片を含む砕屑性石灰岩 (2.5m) が露出する。本露頭の砕首性石灰岩は分布が孤立し ており、周囲の石灰岩との層位関係は特定しがたい が、（1）沖縄養蜂振興入口の東約 $150 \mathrm{~m}$ の露頭（Fig. 3の32）で夕られるサブユニット $3 \mathrm{C}$ のンゴ石灰 岩より地形的に高所に位置することからサブユニッ

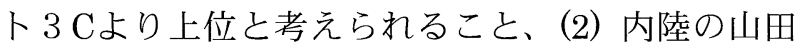
城趾一帯でみられるサブユニット $4 \mathrm{R}$ と分布高度が ほぼ等しいことより、サブユニット $4 \mathrm{R}$ 含められ る可能性がある。仲泊付近には、ほぼ南北方向の断 層（東落ち）がある。この断層の東側に位置する仲 泊遺跡（Fig. 3の34）では、砕屑性石灰岩（層厚 $3.5 \mathrm{~m}$ ）の上位にサンゴ石灰岩（層厚 $12 \mathrm{~m}$ ） が整合 漸移の関係で重なる。砕屑性石灰岩は、塊状無層理 で、石英片を含む。サンゴ石灰岩は半球状〜卓状サ ンゴに富む。久良波の東に分布するユニット 2 は礫 岩および砂質〜䃇質石灰岩からなること、断層が東 落ちであることから、砕屑性石灰岩とその上位のサ ンゴ石灰岩は、ユニット 2 より上位のユニットに含 められると推定されるが、どのユニットかは特定し がたい。一方、Takayasu（1978）は、断層の西側 に位置する山田温泉（現ルネッサンスリゾートオキ ナワ）向かいの露頭、すなわち仲泊遺跡の北方の露 頭では、琉球層群下部層（サブユニット $3 \mathrm{R}$ 対応 すると推定される）が非石灰質砂岩層（ユニット 2 に対応すると推定される）を整合漸移の関係で覆う と報告している。しかし、この露頭は現在コンクリー トで覆われており、その関係を追認することはでき ない。この露頭より地形的に高所には標高約 $40 \mathrm{~m}$ のやや平坦な面があり、サンゴ石灰岩が散点的に分 布し、これはサブユニット $4 \mathrm{C}$ に含められると推定
される。ムーンビーチからタイガービーチ一帯 （Fig. 3の35）には、半球状サンゴを多く含むサン ゴ石灰岩が広く分布する。本サンゴ石灰岩は分布が 孤立しているため、どのユニットに含められるのか は不明である。本サンゴ石灰岩の層厚は最大で 10 m以上に達し、読谷地域から恩納村西部にかけての 一帯に分布する琉球層群では、そのような大規模な ものはサブユニット $4 \mathrm{C}$ のである。したがって、 読谷地域から恩納村西部では、複数の東落ちの正断

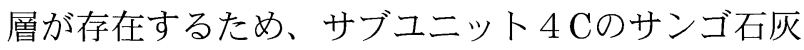
岩が、それらの正断層により、北東に向かい徐々に その高度を下げ、タイガービーチ一帯に分布してい る可能性が考えられる。

\section{5. 山田城趾一帯における層序}

本調查地域の内陸部の山田城趾の西には、サンゴ 石灰岩が分布する（Fig. 3の36、40４2）。一方、 本調査地域に隣接する読谷地域では、サブユニット $4 \mathrm{C}$ のンゴ石灰岩が広く分布し、その層厚は $20 \mathrm{~m}$ に及ぶ。このサンゴ石灰岩はFlint et al. (1959) の読谷石灰岩に相当し（小田原ほか 2005）、いわ ゆる中位段丘（木庭 1980 ; 河名 1988）上に広く 露出する。山田城趾の西のサンゴ石灰岩は、読谷地 域のサブユニット $4 \mathrm{C}$ と同一地形面上に分布し、層 厚は $10 \mathrm{~m}$ 超える。よって本論では、山田城趾の 西のサンゴ石灰岩は、サブユニット $4 \mathrm{C}$ 含められ る蓋然性が高いと判断する。

山田城趾の西に位置する琉球村に面した急崖 （Fig. 3の37）には、層厚が15.0mにも及ぶ砕屑性 石灰岩が露出する。この砕屑性石灰岩は、やや固結 度が低く、淘汰がよく、最下位より $4.5 〜 8.3 \mathrm{~m} に は$ 異地性の造礁サンゴを多く含む層が挟在する。本砕 屑性石灰岩は、付近に分布するサブユニット $4 \mathrm{C}$ （Fig. 3の36、39、40）のサンゴ石灰岩の直下に位 置すると判断されるので、サブユニット $3 \mathrm{R}$ 亿含め られる。本露頭の近傍では、旧国道58号線に沿つ て、沖縄身体障害者福祉工場向かいの露頭から琉球 村の向かいの露頭（Fig. 3の38）にかけて約 $380 \mathrm{~m}$ にわたり砕屑性石灰岩が断続的に露出し、これらも サブユニット 3 Rに含められる。琉球村の向かいの 露頭（Fig. 3の38）では層厚が17.4mに達する砕屑 性石灰岩が分布し、その下位には整合漸移の関係で 石灰藻球石灰岩（層厚 $2.5 \mathrm{~m} ）$ がみられる。サブユ

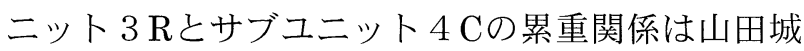


趾護佐丸父祖墓の南西約 $450 \mathrm{~m}$ に位置する露頭 (Fig. 3の39) で観察される。ここでは、サブユニッ ト $3 \mathrm{R}$ の砕屑性石灰岩（層厚 $3.7 \mathrm{~m}$ ）の上位にサブ ユニット $4 \mathrm{C}$ エンゴ石灰岩（層厚 $0.7 \mathrm{~m}$ ）が重な る。砕屑性石灰岩は塊状無層理で、サンゴ、サンゴ モ、コケムシ、イントラクラスト（石灰藻球石灰岩 の礫）を含む。サンゴ石灰岩には現地性の卓状サン ゴおよび枝状サンゴの破片が含まれる。両者は極め て明瞭な境界をもって接し、岩相はこの境界をもつ て急変する。よって、ここではサブユニット $3 \mathrm{R}$ と サブユニット $4 \mathrm{C}$ は不整合関係にあると推定される。 山田城趾護佐丸父祖墓の南西約 $500 \mathrm{~m}$ に位置する 2 露頭（Fig. 3の41、42）では、サンゴ石灰岩中に 淘汰のよい砕屑性石灰岩が挟在する。北西側の露頭 (Fig. 3の41）では、下位より、サブユニット $4 \mathrm{C}$ のサンゴ石灰岩（層厚1.8〜 3.2m）、淘汰のよい砕 屑性石灰岩（層厚1.9〜 3.3m)、サンゴ石灰岩（層 厚 $4.2 \mathrm{~m}$ ）という累重関係がみられる。砕屑性石灰 岩は、その上位および下位に位置するサンゴ石灰岩 と整合漸移にあり、顕微鏡下においては、Calcarina をはじめとする底生有孔虫が豊富にみられ、サンゴ モや非石灰質岩片などが伴って認められる。また、 南東側の露頭（Fig. 3の42）では、淘汰のよい砕屑 性石灰岩（層厚 $5 \mathrm{~m}$ ）の上位にサンゴ石灰岩（層厚 $2.5 \mathrm{~m})$ が整合漸移で重なる。砕屑性石灰岩は無節 サンゴモに富み、二枚貝や巻貝を含む。サンゴ石灰 岩は薄板状〜卓状サンゴに富む。このような産状の 砕屑性石灰岩は、本地点付近でのみ認められ、分布 は局所的である。この砕屑性石灰岩は、上下のサン ゴ石灰岩と整合漸移の関係で接し、側方への連続性 に乏しい。また、淘汰がよく、沖合相を特徴づける 生砕物を欠く。よって本砕屑性石灰岩はサブユニッ 卜 $4 \mathrm{C}$ に含められる浅海性の堆積物と解釈される。 一方、山田城趾護佐丸父祖墓裏（Fig. 3の43）では、 サンゴ石灰岩（層厚 $8.5 \mathrm{~m}$ ）の下位に砕屑性石灰岩 （層厚 $5.5 \mathrm{~m}$ ）が分布する。この砕屑性石灰岩は、塊 状無層理で、鏡下で底生有孔虫 (Amphistegina、Ca lcarina、Operculina等)、コケムシ、サンゴモ、ウニ、 二枚貝などの生砕物およびイントラクラストが認め られ、沖合相（淘汰の悪い砕屑性石灰岩; Nakamo ri 1986）に含められる。この砕屑性石灰岩亡上位 のサンゴ石灰岩とは整合漸移の関係にある。本地点 より地形的に低所では、サブユニット $4 \mathrm{C}$ サンゴ 石灰岩が、サブユニット $3 \mathrm{R}$ 砕屑性石灰岩上に不
整合で重なる（Fig. 3の39）のに対し、地形的に高 所にある本露頭では、砕屑性石灰岩とその上位のサ ンゴ石灰岩は整合漸移の関係にある。したがって下 位の砕屑性石灰岩はサブユニット $4 \mathrm{R}$ に、上位のサ ンゴ石灰岩はサブユニット $5 \mathrm{C}$ に含めるのが最も妥 当と思われる。

\section{2. 新期石灰岩 (Younger limestones)}

〈層厚〉 $4 \mathrm{~m}$ 以上。

〈分布〉美留の海岸線から北西約 $50 \mathrm{~m}$ の地点に位

置する小島、塩屋漁港内漁業センタ一脇の露頭、 真栄田岬頂部。

〈岩相〉楚辺層の上位に不整合関係で重なるサンゴ 石灰岩および挽屑性石灰岩で、いずれも層厚 4 $\mathrm{m}$ 以下の小規模な岩体である。

美留の海岸線の北西約 $50 \mathrm{~m}$ の地点に位置する小 島（Fig. 3の 7 ） では、新期石灰岩に含められるサ ンゴ石灰岩（層厚 $3 \mathrm{~m}$ ）が、サブユニット $3 \mathrm{R}$ の石 灰藻球石灰岩（層厚 $2 \mathrm{~m}$ ）を不整合関係で覆う (Fig. 4A)。両者の境界は、北西側に約 $25^{\circ}$ 傾斜して おり、極めて明瞭である。サンゴ石灰岩には半球状 〜卓状サンゴが少量含まれ、無節サンゴモはみられ ない。また、塩屋漁港内漁業センター脇の露頭 （Fig. 3の10）では、サブユニット3 Rの砕屑性石 灰岩の上位にサンゴ石灰岩が重なる。両者の境界は 極めて明瞭で、起伏に富んでいる（Fig. 4B)。ま た、砕屑性石灰岩の上部1.3mは著しく赤色化して いる。サンゴ石灰岩はMontipora、Goniopora、

Euphyllia等の卓状、半球状、太枝状の造礁サンゴに 富む。前述のように、真栄田岬ではサブユニット 4 Cのサンゴ石灰岩がサブユニット $3 \mathrm{R}$ 砕屑性石灰 岩上に整合関係で、山田城趾護佐丸父祖墓裏（Fig.

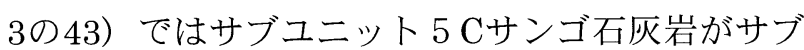
ユニット $4 \mathrm{R}$ 砕屑性石灰岩の上に整合関係で重なっ ており、より標高の低い両露頭で、サブユニット 3 Rの石灰藻球石灰岩や砕屑性石灰岩亡不整合関係に あるサンゴ石灰岩をサブユニット $4 \mathrm{Cやサブユニッ}$ ト $5 \mathrm{C}$ に含めることはできない。したがって、両露 頭のサンゴ石灰岩は、楚辺層を不整合に覆う新期石 灰岩に含められるべきである。

真栄田岬（Fig. 3の17）の頂部には新期石灰岩に 含められる砕屑性石灰岩（bioclastic rudstone）が 分布し、下位のサブユニット $5 \mathrm{C}$ のサンゴ石灰岩と は、起伏をもった極めて明瞭な境界で接する（Fig. 
4C)。本砕屑性石灰岩は、下位の琉球層群に由来す る石灰岩礫を含有することを特徽とする。また、二 枚貝の破片が多く含まれ、サンゴモ、ウニ、サンゴ が認められる。

\section{年 代}

本研究では琉球層群の年代を決定するために、石 灰質ナンノ化石の検出を試みた。検討した 34 試料 のうち、久良波の東約 $130 \mathrm{~m}$ 地点の露頭（Fig. 3の 29）に露出するユニット 2 の砂質石灰岩より採取 した 2 試料から、石灰質ナンノ化石が産出した。 それらの石灰質ナンノ化石は保存状態が悪かつたが、 Pseudoemiliania lacunosa, Reticulofenestra spp. (sm all)、および Gephyrocapsa spp. (small)の産出が確 認された。よって、本地域の楚辺層ユニット 2 は佐 藤ほか（1999）の基準面 3〜11に対比される。そ の年代は0.41〜1.65Maである。小田原ほか（2005）

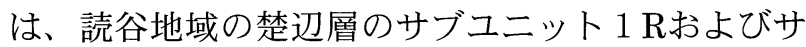
ブユニット $2 \mathrm{R}$ の砂質石灰岩より石灰質ナンノ化石 を検出し、その年代が $0.41 \sim 0.85 \mathrm{Ma}$ （基準面 $3 \sim$ 5 ）であることを報告している。本研究の成果はこ れと矛盾しない。

\section{地 史}

本調査地域に分布する琉球層群主部（楚辺層）堆 積時の地史は以下のように推定される。なお、琉球 層群堆積時における海水準変動と島の隆起・沈降は 分離して考えることはできないので、沖縄本島の上 下運動はなかったものとし、本調査地域を固定した 上で、サンゴ礁の形成史を解釈する。

\section{1. 楚辺層ユニット 2 堆積時}

本調査地域において、本ユニットに含められる堆 積物は、真栄田岬〜久良波の急崖における久良波側 基部から山田温泉の南にかけての一帯に分布する碟 岩、礫質砂岩、砂質〜碟質石灰岩のみであり、分布 や岩相の空間配置が不明確であるため、本ユニット 堆積時の礁性堆積物の発達状況は不明である。本工 ニットの堆積物は、基盤岩（名護層）に由来する砕 屑物を多く含むことによって特徵づけられることよ
り、その堆積時には、浅海域における基盤岩の削剥 が活発に行われ、そこから多量の陸源性砕屑物がも たらされたと推定される。また、本ユニットの堆積 物に琉球層群の礫が見出されないことより、下位の ユニット 1 の堆積域は限られており、当時の基盤岩 の分布域を広く覆つていなかったことを示唆する。 これは、読谷地域において、ユニット 1 の分布が極 めて限られていること（小田原ほか 2005）と調和 的である。久良波側基部の標高約 $15 \mathrm{~m}$ に分布する 砂質砂岩にはOperculinaが比較的多く含まれる。現 在の琉球列島では、Operculinaは水深30m以深で多 く見出されるので（古田土・中川 1993 ; Hoheneg ger et al. 2000)、ユニット 2 の堆積時に旧汀線は 現在の標高 $45 \mathrm{~m}$ 以上に達したと考えられる。これ は、読谷地域ではユニット 2 堆積時の高海水準期に

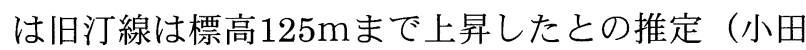
原ほか 2005）と矛盾しない。

\section{2. 楚辺層ユニット 3 堆積時}

ユニット 2 の堆積後、旧汀線は低下し、サブユニッ ト 3 Cが堆積した。沖縄養蜂振興入口の東方約 150 $\mathrm{m}$ の露頭（Fig. 3の32）では、ユニット 2 の碟質石 灰岩の上位にサブユニット $3 \mathrm{C}$ のンゴ石灰岩が比 較的明瞭な境界をもつて重なり、下位の碟質石灰岩 の上面は赤色を帯びていることより、碟質石灰岩は 堆積後に一時的に干出した可能性が指摘される。よつ て、ユニット 2 の堆積後、旧汀線は現在の標高約 $25 \mathrm{~m}$ 付近まで低下したと推定される。その後、サ ブユニット $3 \mathrm{R}$ の堆積物が堆積した。真栄田岬ダイ バーズハウスの東約 $120 \mathrm{~m}$ 露頭（Fig. 3の31）で は標高約50mでCycloclypeusがみられる。現在の琉 球列島では、Cycloclypeusの遺骸は水深 $100 \mathrm{~m}$ 前後で 多く認められるので (Iryu et al. 1995 ; Hoheneg ger and Yordanova 2001)、サブユニット $3 \mathrm{R}$ 堆 積時に、旧汀線は現在の標高約 $150 \mathrm{~m}$ まで昇した と推定される。サブユニット $3 \mathrm{R}$ の砕屑性石灰岩に は、造礁サンゴの礫を豊富に含む層が挟在し（Fig. 3の12、13、14、16、37)、これは他のサブユニッ 卜の砕屑性石灰岩には認められない特徵である。こ の富造礁サンゴ碟層は、読谷地域の楚辺層のサブユ ニット $3 \mathrm{R}$ 中にも挟在する。よって、サブユニット 3 Rの堆積時には、沖合相の堆積域に広範にわたつ てサンゴ礫が多量に供給されたことが確実である。 その理由としては、海進の一時停止もしくは小規模 
な海退とそれに伴う礁の沖合側への移動や礁浅海部 の地形の変化等が考えられるが、現時点では、地質 学的な証拠に基づいて特定することはできず、今後、 検討を要する。なお、小田原ほか（2005）は、読 谷地域ではユニット 3 の低海水準期の旧汀線が標高 $25 \mathrm{~m}$ 、高海水準期の旧汀線が標高 $140 \mathrm{~m}$ であるとし ている。これと本研究の結果とは矛盾しない。

\section{3. 楚辺層ユニット 4 堆積時}

ユニット 3 の堆積後、旧汀線は低下した。小田 原ほか（2005）は、読谷地域では、標高20m以上 の地点ではサブユニット $4 \mathrm{C}$ はサブユニット $3 \mathrm{R} の$ 上位に不連続面をもって重なるが、海岸沿いの標高 $20 \mathrm{~m}$ 以下の地点では両サブユニットは整合関係に あることから、サブユニット $3 \mathrm{R}$ の堆積後、旧汀線 は現在の標高 $20 \mathrm{~m}$ にで低下したと推定した。本 調査地域においては、真栄田岬一帯（Fig. 3の13、 15～19）では両サブユニットの境界は標高 $20 \mathrm{~m}$ 未 満であり、いずれの露頭においても整合関係にある ことが確認された。また、山田城趾護佐丸父祖墓の 南西約 $450 \mathrm{~m}$ に位置する露頭（標高 $83.7 \mathrm{~m}$; Fig. 3 の39）では、両者は不整合関係にあると推定され る。しかしながら、両サブユニットの境界が標高 $43.5 \mathrm{~m}$ 付近にある、真栄田岬ダイバーズハウスから 久良波集落へ抜ける小道沿いにある墓脇の露頭 （Fig. 3の30）では、溶解と続成生成物のため、両 サブユニットの関係を決定することができなかった。 よって、本調査地域では、サブユニット $4 \mathrm{C}$ 堆積後 に旧汀線がどこまで低下したかを決定することはで きない。旧汀線の低下後、相対的海進に伴って、礁 は内陸部へと分布を広げ、現在本地域内陸部を広く 覆うサブユニット $4 \mathrm{C}$ のサンゴ石灰岩が堆積し、次 いで、サブユニット $4 \mathrm{R}$ の堆積物が堆積した。山田 城趾護佐丸父祖墓（Fig. 3の43）でみられる本サブ ユニットの堆積物（標高約 $75 \mathrm{~m} ）$ にはOperculinaが 比較的多く含まれているので、この時期には、旧汀 線は現在の標高約 $105 \mathrm{~m}$ 以上まで上昇したと思われ る。なお、小田原ほか（2005）は、読谷地域では、 本サブユニット堆積時には旧汀線が標高 $130 \mathrm{~m}$ ま゙ 上昇したと述べており、これは本研究の結果と矛盾 しない。

\section{4. 楚辺層ユニット 5 堆積時}

ユニット 4 の堆積後に海水準は低下し、真栄田岬
や山田城址でみられるサブユニット 5 Cが堆積した。 山田城址の露頭（Fig. 3の43）では、本サブユニッ トのサンゴ石灰岩とサブユニット $4 \mathrm{R}$ の砕屑性石灰 岩が整合関係にあることより、旧汀線は現在の標高 $77 \mathrm{~m}$ 以下には達しなかったと推定される。しかし、 小田原ほか（2005）は、読谷地域の琉球層群の検 討結果に基づいて、同時期の旧汀線の低下を標高 $65 \mathrm{~m}$ と見積もつており、これは本研究の結果とは 必ずしも一致しない。

\section{まとめ}

本研究において、以下の点が明らかになつた。

1. 真栄田岬一帯の琉球層群は、楚辺層とそれを不 整合に覆う新期石灰岩よりなる。

2. 本調査地域の楚辺層は 4 つのユニットに区分さ れ、それらは模式地（読谷村）における楚辺層 ユニット $2 〜 5$ （小田原ほか 2005）に対比さ れる。本調査地域では、ユニット 2 は主に砂岩 および砂質〜砂質石灰岩よりなり、ユニット 3 および 4 は浅海相であるサンゴ石灰岩とその沖 合相である确屑性石灰岩・石灰藻球石灰岩・ Cycloclypeus-Operculina石灰岩から構成される。 ユニット 5 はサンゴ石灰岩のみからなり、それ に対応する沖合相はみられない。

3. 新期石灰岩はサンゴ石灰岩および砕屑性石灰岩 よりなり、真栄田岬頂部、塩屋漁港内漁業セン 夕一脇の露頭、美留の海岸線から北西約 $50 \mathrm{~m} の$ 地点に位置する小島に分布する。各石灰岩の分 布は孤立しているため、それら相互の層位学的 関係は不明である。

4. 本地域の楚辺層ユニット 2 の砂質石灰岩から石 灰質ナンノ化石が検出された。その年代は、 0.41〜1.65Maであり、小田原ほか（2005）の 年代と矛盾しない。

謝辞 本論文は、村岡暖子の東北大学理学部地圈環 境科学科卒業論文の成果の一部をまとめたものであ る。読谷〜恩納村西部にかけての一帯に分布する琉 球層群の研究を進めるに際しては、熊本大学理学部 の松田博貴助教授、広島大学大学院理学研究科の狩 野彰宏助教授、金沢大学大学院自然科学研究科の山 田茂昭博士に多くの助言を頂いた。恩納村元教育長 
の伊波肇氏をはじめとする恩納村役場の方々、恩納 村の真栄田岬ダイバーズハウスのスタッフの方々に は、現地調査に際して、多くの便宜をはかっていた だいた。東北大学理学部地圈環境科学科の佐々木洋 明元技官には薄片作成に際し、協力していただいた。 また， 2 名の査読者には，多くの建設的コメントを いただいた。以上の方々に、記して篤く御礼申し上 げる。

\section{引用文献}

Flint DE, Saplis RE, Corwin G (1959) Military Geology of Okinawa-jima, Ryukyu-retto, vol. 5. Geol Surv Branch, Intell Div, Office Eng, Hq, U S Army Pacific with personnel of U S Geol Surv, 88p

Hohenegger J, Yordanova E (2001) Displacement of larger foraminifera at the western slope of Motobu Peninsula (Okinawa, Japan). Palaios, 16: $53-72$

Hohenegger J, Yordanova E, Hatta A (2000) Remarks in west Pacific Nummulitidae (Foraminifera). J Foram Res, 30: 3-28 井龍康文・松田博貴（1999）浅海堆積物掘削に関 する提言 一炭酸塩堆積物に関して一。 月刊地球, 21: $735-741$

井龍康文・中森 亨 - 山田 努（1992）琉球層群 における層序区分単位. 堆積学研究会報, $36: 5$ 7-66

Iryu Y, Nakamori T, Matsuda S, Abe O (1995) Distribution of marine organisms and its geological significance in the modern reef complex of the Ryukyu Islands. Sedim Geol, 99: 243-258

Iryu Y, Nakamori T, Yamada T (1998) Pleistocene reef complex deposits in the Central Ryukyus, southwestern Japan. In: Camoin G, Davies PJ (eds) Reefs and Carbonate Platforms in the Pacific and Indian Oceans. Spec Publ Int Sed Ass, no. 25, Blackwell Sci, Oxford, pp 197-213

河名俊男（1988）シリーズ沖縄の自然(3) 琉球列 島の地形．新生図書出版，那覇， $127 \mathrm{p}$
木庭元晴（1980）琉球層群と海岸段丘．第四紀研 究，18: 189-208

古田土 俊夫 - 中川 洋 (1993）琉球列島宮古島 西方海域の現世炭酸塩堆積物中の底生有孔虫群集. 石油公団石油開発技術センター研究報告，24: 93-110

松田博貴・井龍康文・町山栄章 (2003) 科学提案 「琉球弧におけるサンゴ礁前線の移動：北西太平 洋での第四紀気候変動に対する高緯度サンゴ礁の 呼応」の科学的背景と掘削計画概要. 月刊地球号 外, 40: $292-298$

Nakamori T (1986) Community structures of Recent and Pleistocene hermatypic corals in the Ryukyu Islands, Japan. Sci Rep Tohoku Univ, 2nd Ser. (Geol), 56: 71-133

Nakamori T, Iryu Y, Yamada T (1995) Development of coral reefs of the Ryukyu Islands (southwest Japan, East China Sea) during Pleistocene sea-level change. Sedim Geol, 99: 215-231

小田原 啓・井龍康文（1999）鹿児島県与論島の 第四系サンゴ礁堆積物（琉球層群）。地質雑, 105: 273-288

小田原 啓 - 工藤茂雄 - 井龍康文 - 佐藤時幸 （2005）沖縄本島読谷村一帯の座喜味層および琉 球層群の層序．地質雑，111：313-331

Sagawa N, Nakamori T, Iryu Y (2001) Pleistocene reef development in the southwest Ryukyu Islands, Japan. Palaeogeogr Palaeoclimatol Palaeoecol, 175: 303-323

佐藤時幸・亀尾浩司・三田 薰（1999）石灰質ナ ンノ化石による後期新生代地質年代の決定精度と テフラ層序. 地球科学, 53: 265-274

佐藤時幸・中川 洋・小松原純子・松本 良・井龍 康文・松田博貴 - 大村亜希子 - 小田原 啓 - 武内 里香（2004）石灰質微化石層序からみた沖縄本 島南部，知念層の地質年代. 地質雑，110：28-50 Takayasu K. (1978) "Ryukyu Limestone" of Okinawa-jima, south Japan -a stratigraphical and sedimentological study-. Mem Fac Sci. Kyoto Univ, Ser Geol Mineral, 45: 133-175

(Received: 26 April 2005/ Accepted: 9 Aug. 2005) 


\section{沖縄本島真栄田岬一帯の琉球層群の層序}

村岡暖子 ${ }^{1} \cdot$ 井龍康文 $^{1} \cdot$ 小田原 啓 ${ }^{1,2}$

山田 努 $^{1} \cdot$ 佐藤時幸 $^{3}$

${ }^{1}$ 東北大学大学院理学研究科地学専攻地圈進化学講座

2 神奈川県温泉地学研究所

${ }^{3}$ 秋田大学工学資源学部地球資源学科応用地球科学教 室

沖縄本島中部の真栄田岬一帯に分布する第四系は、 更新統のサンゴ礁複合体堆積物である琉球層群と完新 統の海岸および低地堆積物よりなり、これらは先第三 系の名護層を不整合に覆う。調査地域の琉球層群はそ の主体を占める楚辺層と新期石灰岩に区分される。調 查地域の楚辺層は 4 つのユニットの累重体である。最 下位のユニットは主に碟岩および砂質〜砂質石灰岩よ りなり、その上位の 2 つのユニットは低海水準期の浅 海相であるサンゴ石灰岩から高海水準期の沖合相であ る石灰藻球・Cycloclypeus-Operculina ・ 砕屑性石灰岩へ と上方深海化する整合一連のシーケンスから構成され る。最上位のユニットはサンゴ石灰岩のみからなる。 本層の分布高度は $90 \mathrm{~m} に 及 ひ ゙ 、$ 層厚は $35 \mathrm{~m}$ に達する。 新期石灰岩は、調查地域の海岸部の 3 地点で認められ、 楚辺層を不整合で覆うサンゴ石灰岩および楚辺層に由 来する石灰岩の碩を含有する砕屑性石灰岩よりなる。 これらの石灰岩は、いずれも層厚 $4 \mathrm{~m}$ 以下の小規模な 岩体である。それぞれの岩体は孤立して分布しており、 相互の関係は不明である。なお、ユニット 2 の砂質石 灰岩より石灰質ナンノ化石が産出し、その年代は 0.41 〜 1.65Maである。 